RED SCARE 
THIS PAGE INTENTIONALLY LEFT BLANK 


\section{RED SCARE}

Right-Wing Hysteria,

Fifties Fanaticism,

and Their Legacy

in Texas

\section{BY DON E. CARLETON}

University of Texas Press 
Copyright (C) 1985 by Don E. Carleton

All rights reserved

Printed in the United States of America

Originally published as Red Scare!: Right-wing Hysteria, Fifties Fanaticism, and Their Legacy in Texas by Texas Monthly Press

First University of Texas Press edition, 2014

Requests for permission to reproduce material from this work should be sent to:

Permissions

University of Texas Press

P.O. Box 7819

Austin, TX 78713-7819

http://utpress.utexas.edu/index.php/rp-form

The Library of Congress has cataloged the earlier edition as follows:

Carleton, Don E., 1947-

Red scare!

Bibliography: $\mathrm{p}$.

Includes index.

1. Subversive activities-Texas-Houston-History-20th century.

2. Houston (Tex.) - History. 3. Internal security-Texas-Houston-History20th century. I. Title.

F394.H857C37 $1985 \quad 976.4^{\prime} 1411063 \quad 84-24007$

ISBN 978-0-292-75855-1

doi:10.7560/758551

ISBN 978-0-292-75856-8 (library e-book)

ISBN 978-0-292-75857-5 (individual e-book) 
To the memory of

Genvieve Marie Carleton

Ernest G. Young

and Louis J. Kestenberg 
THIS PAGE INTENTIONALLY LEFT BLANK 